\title{
Reaction norms in weights at 365 days old in nellore bulls in northern Brazil
}

\section{Norma de reação para pesos aos 365 dias de idade em bovinos Nelore do Brasil}

\author{
Jorge Luís Ferreira ${ }^{1 *}$; Alliny Souza de Assis ${ }^{2}$; Fernando Brito Lopes ${ }^{3}$; \\ Thomas Wayne Murphy ${ }^{4}$; Marcelo Corrêa da Silva ${ }^{5}$; José Américo Soares Garcia ${ }^{6}$; \\ Ednira Gleida Marques ${ }^{7}$
}

\begin{abstract}
Genotype by environment interaction (GxE) studies are of particular interest in Brazil because of the regional diversity of environmental effects and the wide variety of management systems. The present study evaluates GxE effects on 365 d weight (365W) of Nellore cattle raised on pasture in northern Brazil. The analysis utilized random regression techniques to model the reaction norm. Fixed effects consisted of sex, contemporary group, and the covariate of age of cow at calving. The environmental gradient, defined by the concatenation of a bull and the state in which the calf was born, was modelled by second order Legendre polynomials. Direct additive genetic and residual effects were fit as random. Results showed differences in the magnitude of expression of genotype in proportion to decreasing favorability of the environment. As the environment became more unfavorable, the correlation of breeding value to different environments decreased. The correlations between the intercept and the level slope for $365 \mathrm{~W}$ feature were of moderate magnitude, predominantly indicating the reclassification of sires in different environments. Reaction standard model was coherent from a technical and biological view point and enabled the perception of GxE in the genetic evaluation of Nellore cattle in the states of Maranhão, Pará and Tocantins.
\end{abstract}

Key words: Animal breeding, growth, random regression

\section{Resumo}

No Brasil, estudos de interações genótipo x ambiente tem atraído cada vez mais atenção em programas de melhoramento devido à variedade de sistemas de produção e à diversidade ambiental. Objetivou-se avaliar o efeito da interação genótipo $\mathrm{x}$ ambiente sobre o peso ajustado aos 365 dias de idade de bovinos da raça Nelore criados a pasto na região norte do Brasil. As análises foram realizadas utilizando-se regressão aleatória para modelar a norma de reação. Foi considerado como efeitos fixos o sexo, os

\footnotetext{
${ }^{1}$ Prof. Dr., Universidade Federal do Tocantins, UFT, Campus de Araguaína, Araguaína,TO, Brasil. E-mail: jorgeuft@gmail.com

2 Médica Veterinária, Discente do Curso de Mestrado do Programa de Pós-Graduação em Ciência Animal, Escola de Veterinária e Zootecnia, Universidade Federal de Goiás, UFG, Campus Samambaia, Goiânia, GO, Brasil. E-mail: linyasa@hotmail.com

${ }^{3}$ Post-Doctoral, Department of Animal Sciences, University of Wisconsin, Madison, Wisconsin, USA. E-mail: camult@gmail.com

${ }^{4}$ Ph.D., Department of Animal Sciences, University of Wisconsin, Madison, Wisconsin, USA. E-mail: twmurph88@gmail.com

${ }^{5}$ Médico Veterinário, Discente do Curso de Doutorado do Programa de Pós-Graduação em Ciência Animal, Escola de Veterinária e Zootecnia, UFG, Campus Samambaia, Goiânia, GO, Brasil. E-mail: marcelo-correadasilva@hotmail.com

${ }^{6}$ Prof. Associado I, Faculdade de Agronomia e Veterinária, Campus Darcy Ribeiro, Universidade de Brasília, UNB, Brasília, DF, Brasil.E-mail: jasgarcia@unb.br

7 Zootecnista, M.e, Associação Brasileira de Criadores de Zebu, ABCZ, Uberaba, MG, Brasil. E-mail: gleidamarques@hotmail.com

* Author for correspondence
} 
grupos de contemporâneos e como covariável a idade da vaca ao parto. A gradiente ambiental, foi definida pela concatenação entre o touro e a respectiva unidade federativa de nascimento do animal e modelada por meio de polinômios de Legendre de segunda ordem. Como efeito aleatório, foram considerados os efeitos genéticos aditivos diretos e residuais. Os resultados demonstraram diferenças na magnitude da expressão de seu genótipo à proporção que o ambiente tornava-se desfavorável. Ou seja, à proporção que o ambiente torna-se desfavorável, menores seriam as correlações dos valores genéticos nos diferentes ambientes. As correlações entre o intercepto e o nível de inclinação da reta para a característica P365 foram de magnitude moderada, indicando predominantemente reclassificação dos valores genéticos dos animais nos diferentes ambientes. O modelo de norma de reação foi coerente do ponto técnico e biológico de visualizar na avaliação genética da população Nelore criada nos Estados do Maranhão, Pará e Tocantins, a interação genótipo ambiente.

Palavras-chave: Crescimento, melhoramento genético animal, regressão aleatória

\section{Introduction}

Brazil is a large country that has many different production systems for beef cattle. Most of these differences are due to availability of natural resources in its different regions, edaphoclimatic conditions, and economic differences. This diversity provides different opportunities of genotypic expression for animals of the same sire, which makes the identification and proliferation of superior animals all the more difficult (LOPES et al., 2008, 2012). In this sense, one of the main goals of livestock improvement seems to be the production of animals with economically consistent performance in specific management and environmental settings (CAMPÊLO et al., 2001). The magnitude of genetic gain in traits of economic importance is dependent upon the accuracy of production records, reliable estimates of genetic and phenotypic parameters, and the breeding objective for a particular production system (DUBEUF; BOYAZOGLU, 2009). New methodologies that aim to more accurately identify genetically superior animals continue to be developed in the field of animal breeding.

Random regression models have been increasingly used in recent years (BOLIGON et al., 2009, 2011; MACEDO et al., 2009). They enable animal breeders to study longitudinal traits, that is, traits that are measured several times throughout an animal's lifetime. Another application of random regression is in the analysis of longitudinal data on the environmental range, by using reaction norm models. Reaction norm models have been applied in studies characterizing the interaction between genotype and environment (GxE).

$\mathrm{GxE}$ is a highly controversial issue among cattle breeders and genetic improvement programs. One of the most important applications of genetic evaluation is to rank animals according to their offspring performance in an environment. However, one animal that is a superior parent for all environmental situations may not exist (SANTANA JÚNIOR et al., 2014). GxE has triggered several studies in beef cattle breeding in countries across the world, including Brazil (BERTRAND et al., 1987; KOLMODIN et al., 2004; SANTANA JÚNIOR et al., 2014).

Interactions between genotype and environment occur when the difference between the performance of two or more genotypes is not equal across environments (KOLMODIN et al., 2002). Several approaches exist to analyze and detect GxE, reaction norm models are one of the most extensively used methods. They allow the visualization of an animal's performance in different environmental and management conditions, thus defining environmental sensitivity (VIA; LANDE, 1984; KIRKPATRICK; HECKMAN, 1990).

Reaction norms indicate where GxE occurs within the supplied range of environments and its magnitude. A reaction norm may be obtained by random regression of environmental descriptors (KOLMODIN et al., 2002; FIKSE et al., 2003). The environmental variable is unknown and defined as 
the mean phenotypic performance of animals in each environment. The reaction norm (JONG; BIJMA, 2002; KOLMODIN et al., 2002) is then defined as a set of phenotypes produced by the genotype of the selection candidate when exposed to varying environments and management conditions.

Reports on the application of reaction norms from animal breeders have become more frequent in recent years. It has been reported that $\mathrm{GxE}$ should be detected with greater precision when the correlation among the environmental sources of variation is used (FIKSE et al., 2003; KOLMODIN et al., 2004). An animal's phenotype is the result of not only genetic and environmental factors but also an often unaccounted for GxE. Therefore, research concerning this latter effect is important to enable breeders to be more confident in their selection of herd sires and replacement animals. The objective of this study was to quantify the genotype by environment interaction for $365 \mathrm{~d}$ weight in pastureraised Nellore cattle by employing reaction norms in random regression models.

\section{Materials and Methods}

The analyses of environmental effects included climatic variables from a total of 498 Brazilian municipalities, namely, 217 from Maranhão, 143 from and 138 from Tocantins. The daily average of climatic variables included: maximum temperature (MAX), minimum temperature (MIN), mean temperature (TEMP), precipitation (PR), vegetal covering estimated by normalized index of vegetation difference (NIVD), relative humidity (RH), altitude (ALT), and temperature and humidity index (THI). All variables were retrieved from databases of the Instituto Brasileiro de Geografia e Estatística, Instituto Nacional de Meteorologia, Instituto Nacional de Pesquisas Espaciais, and the United States Geological Survey. Climatic variables were then standardized by the STANDARD procedure of Statistical Analysis System using a mean of zero and a variance of one (SAS, 2002). Table 1 provides statistics for TEMP, PR, ALT, NIVD, RH, and THI for the three states.

Table 1. Mean, standard deviation and coefficient of variation for mean temperature (TEMP), precipitation (PR), altitude (ALT), vegetation index per normalized difference (NIVD), relative humidity (RH) and temperature and humidity index (THI) of the municipalities of Maranhão, Pará, and Tocantins.

\begin{tabular}{|c|c|c|c|c|c|c|}
\hline State & Variable & Mean & DP & $\mathrm{CV}$ & Minimum & Maximum \\
\hline \multirow{6}{*}{ Maranhão } & TEMP & 32.40 & 0.83 & 2.56 & 31.00 & 33.99 \\
\hline & PR & 1796.40 & 336.25 & 18.72 & 1027.83 & 2571.01 \\
\hline & ALT & 246.82 & 71.80 & 29.09 & 84.83 & 451.98 \\
\hline & NIVD & 0.40 & 0.01 & 1.44 & 0.38 & 0.42 \\
\hline & $\mathrm{RH}$ & 50.03 & 9.78 & 19.55 & 21.81 & 82.64 \\
\hline & THI & 81.28 & 2.14 & 2.63 & 76.84 & 87.55 \\
\hline \multirow{6}{*}{ Pará } & TEMP & 33.95 & 1.13 & 3.34 & 32.00 & 36.00 \\
\hline & PR & 2200.11 & 93.77 & 4.26 & 1963.07 & 2420.05 \\
\hline & ALT & 730.43 & 147.43 & 20.18 & 359.31 & 1140.62 \\
\hline & NIVD & 0.81 & 0.01 & 1.27 & 0.79 & 0.84 \\
\hline & $\mathrm{RH}$ & 69.56 & 10.19 & 14.64 & 45.25 & 98.91 \\
\hline & THI & 87.13 & 2.66 & 3.06 & 81.15 & 94.65 \\
\hline \multirow{6}{*}{ Tocantins } & TEMP & 31.92 & 1.21 & 3.78 & 30.14 & 33.99 \\
\hline & PR & 1091.02 & 100.04 & 9.17 & 830.40 & 1382.69 \\
\hline & ALT & 300.86 & 64.18 & 21.33 & 139.09 & 440.51 \\
\hline & NIVD & 0.41 & 0.01 & 2.54 & 0.38 & 0.44 \\
\hline & $\mathrm{RH}$ & 55.03 & 4.82 & 8.75 & 37.86 & 67.50 \\
\hline & THI & 81.53 & 1.90 & 2.33 & 77.05 & 86.17 \\
\hline
\end{tabular}


Phenotypic data was provided by the Associação Brasileira de Criadores de Zebu which included body weight adjusted to $365 \mathrm{~d}(365 \mathrm{~W})$ from animals born between 1988 and 2008. The final dataset consisted of 8,741 records from animals sired by the 71 bulls that had offspring in all three of the states analyzed. The final pedigree consisted of 14,837 animals. The connectivity between contemporary groups (CGs) was analyzed with AMC (ROSO; SCHENKEL, 2006) which uses a method based on the total number of genetic links. Records from CGs with less than 10 genetic links, CGs with less than four animals, and bulls with less than three offspring were removed. Analyses of variance was conducted to determine if mean $365 \mathrm{~W}$ was different between the three states by using a general linear model (PROC GLM, SAS) that employed Tukey's studentized range test.

Analyses to evaluate the effect of GxE were done in two stages. The first stage consisted of a univariate animal model in which $\mathrm{CG}$, sex of calf, age of cow at calving (ACC), and environmental range (ER) were included as fixed effects. CGs contained information on herd $(n=8)$, year $(n=$

21), and season of birth ( $\mathrm{n}=3$; Season 1: January through April, Season 2: May through August, or Season 3: September through December). ACC was fit as a co-variable with linear and quadratic terms. ER was defined as the concatenation between the sire identifcation and the state in which the calf was born. The univariate animal model is defined below:

$$
y=X b+Z a+e
$$

where $y$ is the vector of $365 \mathrm{~W}$ observations, $b$ is the vector of fixed effects (CG, ACC, and ER), $a$ is the vector of random additive genetic effects, $X$ is a incidence matrix relating $y$ to $b, Z$ is a incidence matrix relating $y$ to $a$, and $e$ is a vector of random residual effects.

The second stage to evaluate GxE was employed to recalculate ER as absolute rates by standardizing them with a mean of zero and standard deviation of one using PROC STANDARD. Random regression analyses were undertaken with the same $\mathrm{CG}$ and ACC as fixed effects and the standardized ER as a covariable. Additive genetic effects were considered random. A second order Legendre polynomial was included to model the effect of ER, shown in the model below:

$$
y_{i j}=E F+\sum_{m=\mathbf{0}}^{k_{b}} b_{m} \phi_{m}\left(t_{i}\right)+\sum_{m=\mathbf{0}}^{k_{A}} \mathbf{1} \alpha_{j m} \phi_{m}\left(t_{i j}\right)+e_{i j}
$$

where, $y_{i j}$ is the $i^{\text {th }}$ weight observation of the $j^{\text {th }}$ animal, $E F$ is a set of fixed effects, $b_{m}$ is a fixed regression coefficient to model mean trajectory of the population, $\phi_{m}\left(t_{i}\right)$ is a function of Legendre polynomials that describes the mean trajectory of the population according to the environmental range; $\phi_{m}\left(t_{i j}\right)$ is a function of Legendre polynomials describing growth curves of each animal $j$ according to environmental range $t_{i}$ for random additive genetic effects, $\alpha_{j m}$ are random regression coefficients of additive genetic effects, $k_{b}$ and $k_{A}$ are the order of the respective Legendre polynomials included in the model, and $e_{i j}$ is the random error associated to the $i^{\text {th }}$ environmental range of the $j^{\text {th }}$ animal.
The variance components and solutions of the models used in the first and second stages were estimated by restricted maximum likelihood in WOMBAT (MEYER, 2007). In the random regression model, heterogenous residual variance was assumed with three classes.

\section{Results and Discussion}

The average THI, which indicates thermal comfort, were $81.28 \pm 2.14,87.13 \pm 2.66$ and $81.53 \pm 1.90$ for Maranhão, Pará, and Tocantins, respectively. THI is a linear combination of air temperature and relative humidity, both of which 
averaged $32.4 \pm 0.83^{\circ} \mathrm{C}$ and $50.0 \pm 9.78 \mathrm{~g} / \mathrm{m}^{3}, 33.95$ $\pm 1.13^{\circ} \mathrm{C}$ and $69.56 \pm 10.1978 \mathrm{~g} / \mathrm{m}^{3}$, and $31.92 \pm$ $1.21^{\circ} \mathrm{C}$ and $55.03 \pm 4.8378 \mathrm{~g} / \mathrm{m}^{3}$ for Maranhão, Pará, and Tocantins, respectively. The average precipitation was $1796.4 \pm 336.25 \mathrm{~mm}, 2200 \pm$ $93.77 \mathrm{~mm}$, and $1091.04 \pm 100.04 \mathrm{~mm}$ for Maranhão, Pará, and Tocantins, respectively. These climatic variables characterize the conditions animals must cope with in order to remain healthy and productive in the Amazon region of Brazil. An optimal THI for cattle production has been estimated at or below 70 (SILVA, 2000). Although a THI above 70 may not cause any animal health problems, cattle breeders may experience slight decreases rate of gain.

According to Martins (2001), the solar energy load on an animal in tropical regions may be as much as three times the total endogenous heat produced by the animal. Absorption of solar radiation by coupled with increases in environmental temperature can considerably influence the production of metabolic heat (ENCARNAÇÃO, 1989). The detrimental effects of solar radiation on animal production may be eased by natural or provided shading. These results may indicate that the environment may have a greater influence on the production of grazing cattle in the states of Maranhão and Tocantins. The majority of the municipalities in these states have average THI above 70. Maranhão and Tocantins are further characterized by high mean temperatures and low precipitation in the timeline studied.

Since animals in these regions are extensively managed on pasture, forage availability is an important factor for beef production and can be quantified by the vegetation index. According to the
Division of Satellite and Environmental Systems (2011), NIVD is a variable that maps and measures vegetation and growing conditions within a determined area. Ponzoni and Shimabukuro (2007) reported that an NIVD of 0.80 was associated with dense vegetation (SILVA et al., 2007). Analysis of NIVD may be employed in studies considering the vegetation growth cycle. The average NIVD was $0.40 \pm 0.01,0.81 \pm 0.01$, and $0.41 \pm 0.01$ for the states of Maranhão, Pará and Tocantins, respectively. Although the state of Pará had the highest average THI of the states analyzed, it also had the highest average precipitation and the greatest vegetation cover which may indicate better natural shading and forage availability. These conditions are conducive to thermal comfort for animals and lends to increases in their growth and production. In combination, these favorable conditions may partially explain the higher mean performance in $365 \mathrm{~W}$ for animals raised in Pará (Table 2). THI and NIVD are highly relevant to analyze the spatial distribution of thermal comfort and the availability of forage in the states under analysis.

The differences of these environmental variables between these states may reveal the possibility of differing environmental effects on the phenotype of the animals raised in different environments. Olesen et al. (2000) showed that the efficient use of genetic resources and their stability in several environments are important factors for successful animal breeding programs. Along with this, McManus et al. (2011) suggested that management and environmental effects should be properly accounted for if in order for a selection program to show genetic gains.

Table 2. Mean (kg), standard deviation (kg) and coefficient of variation (\%) for 365 day weight in Nellore cattle according to state state.

\begin{tabular}{lccc}
\hline \multicolumn{1}{c}{ State } & Mean & Standard deviation & Coefficient of variation \\
\hline Maranhão & $242.81^{\mathrm{B}}$ & 43.78 & 18.03 \\
Pará & $256.96^{\mathrm{A}}$ & 46.42 & 18.07 \\
Tocantins & $226.01^{\mathrm{C}}$ & 39.13 & 17.31 \\
\hline
\end{tabular}

${ }^{\mathrm{ABC}}$ Denotes means are statistically different $(P<0.001)$ among the states; Coefficient of variation of model: $12.75 \%$ 
The solutions for the ERs from the univariate animal model varied between $-97.19 \mathrm{~kg}$ and 81.09 $\mathrm{kg}$, and $80 \%$ of the solutions ranged between -49.97 $\mathrm{kg}(10 \%$ percentile) and $46.22 \mathrm{~kg}(90 \%$ percentile). These results demonstrate the importance of environmental variables between states and how they may affect animal performance. Besides accounting for local conditions in selection programs, animal performance may be affected by a genotype by environment interaction which can create environmental sensitivity (BLACKBURN et al., 1998; OLESEN et al., 2000; PEGOLO, 2005;
McMANUS et al., 2011).

Sensitivity of an animal to the environment is an important aspect that is assesed by reaction norms. The variability of the animal genetic component was tested across environmental situations that took into account different ERs which varied between $-21 \mathrm{~kg}$ and $+21 \mathrm{~kg}$ (Table 3). Results revealed differences in the magnitude of genotypic expression as the environment became more and more unfavorable. In other words, as the environment became unfavorable, the correlation of breeding value in the different environments became smaller.

Table 3. Estimates of linear correlation between expected progeny difference of bulls evaluated in Maranhão, Pará and Tocantins within different environmental ranges.

\begin{tabular}{ccccccc}
\hline & -14 & -7 & 0 & 7 & 14 & 21 \\
\hline-21 & 0.67 & 0.53 & 0.31 & 0.07 & -0.20 & -0.41 \\
& $* * *$ & $* * *$ & $* *$ & Ns & $*$ & $* *$ \\
-14 & & 0.98 & 0.87 & 0.67 & 0.35 & -0.02 \\
& & $* * *$ & $* * *$ & $* * *$ & $* *$ & Ns \\
-7 & & & 0.94 & 0.78 & 0.48 & 0.11 \\
& & $* * *$ & $* * *$ & $* * *$ & Ns \\
0 & & & 0.93 & 0.71 & 0.38 \\
& & & $* * *$ & $* * *$ & $* *$ \\
7 & & & & 0.90 & 0.65 \\
& & & & $* * *$ & $* * *$ \\
14 & & & & & 0.90 \\
\end{tabular}

$*(P<0.05), *(P<0.01), * * *(P<0.001)$, ns (not significant, $P>0.05)$, Spearman's correlation

Lower and inversely proportional estimates were obtained between favorable and unfavorable extremes $(-0.20$ and -0.41$)$ when genetic correlation between environmental ranges for $365 \mathrm{~W}$ are taken into account (Figure 1). The genetic correlation of intermediate environments with favorable and unfavorable environments
(+7 and -7) was basically similar (0.94). In their studies on reaction norms for growth characteristics of beef cattle, Corrêa et al. (2009) and Ribeiro et al. (2009) also reported variations in genetic correlation between environments and suggested a re-classification of animals according to the environmental level. 
Figure 1. Estimates of the genetic correlation for $365 \mathrm{~W}$ among the different environmental ranges.

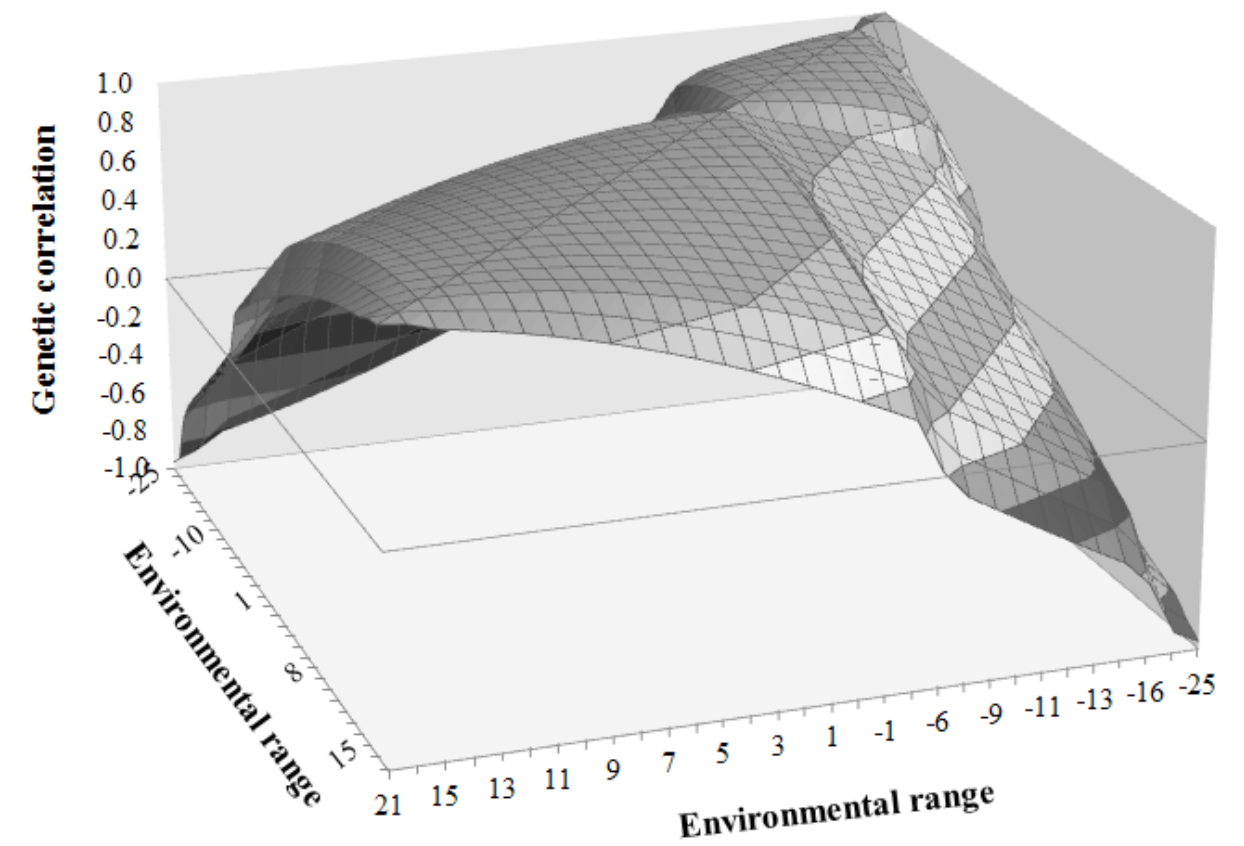

$\square-1.0--0.8 \square-0.8--0.6 \square-0.6--0.4 \square-0.4--0.2 \square-0.2-0.0 \square 0.0-0.2 \square 0.2-0.4 \square 0.4-0.6 \square 0.6-0.8 \square 0.8-1.0$

Without properly accounting for these effects in genetic evaluation programs, selection for more sensitive genotypes may occur which may result in an increase of phenotypic plasticity of in their progeny. This may not be noticeable in favorable environments; however, these genotypes may not perform well in unfavorable environments. Thus, the use of reaction norm may actually provide a greater response to the selection, especially in environments with the best management.

The additive genetic variance for $365 \mathrm{~W}$ varied with ER, increasing as the environment improved. This provided a scale effect for GxE (Figure 2). Variation in additive genetic variance through environmental ranges agreed with results reported by several authors who report an increase in variance in proportion to the environmental range becoming favorable (KOLMODIN et al., 2002; CARDOSO et al., 2004, 2011; SU et al., 2006).

The heterogeneity of variances should be considered since greater additive genetic variance and heritability were estimated as the environment became more favorable. Since the heritability trend is due to the proportion of additive genetic to phenotypic variance, a greater response to selection may be expected for a change in environmental sensitivity. The magnitude of the variance component of the linear regression coefficient is key to evaluate the interaction because the $\mathrm{GxE}$ presupposes differences among these animals. Thus, the correlation between the intercept and the slope $(0.49, P<0.0001)$ showed that the reclassification of animals occurred with variation in environmental range.

High correlations mean the heterogeneity of animal sensitiveness, in other words, it means reaction norms with different slopes for each animal. Similar situations may result in modifications in genetic variance or even modifications in the order of classification of the animals in different environments. On the other hand, low rates presuppose parallel trend of reaction norms along to the environmental axes, with no change in 
additive genetic variance neither classification of the animals along to the ER, and there is no need in such situation to seek the best genotypes in different environments.

Figure 2. Reaction norm of estimates of additive genetic variance $\left(\mathrm{kg}^{2}\right)$ and heritability $\left(\mathrm{h}^{2}\right)$ and their respective standard deviations for $365 \mathrm{~W}$ of Nellore cattle.
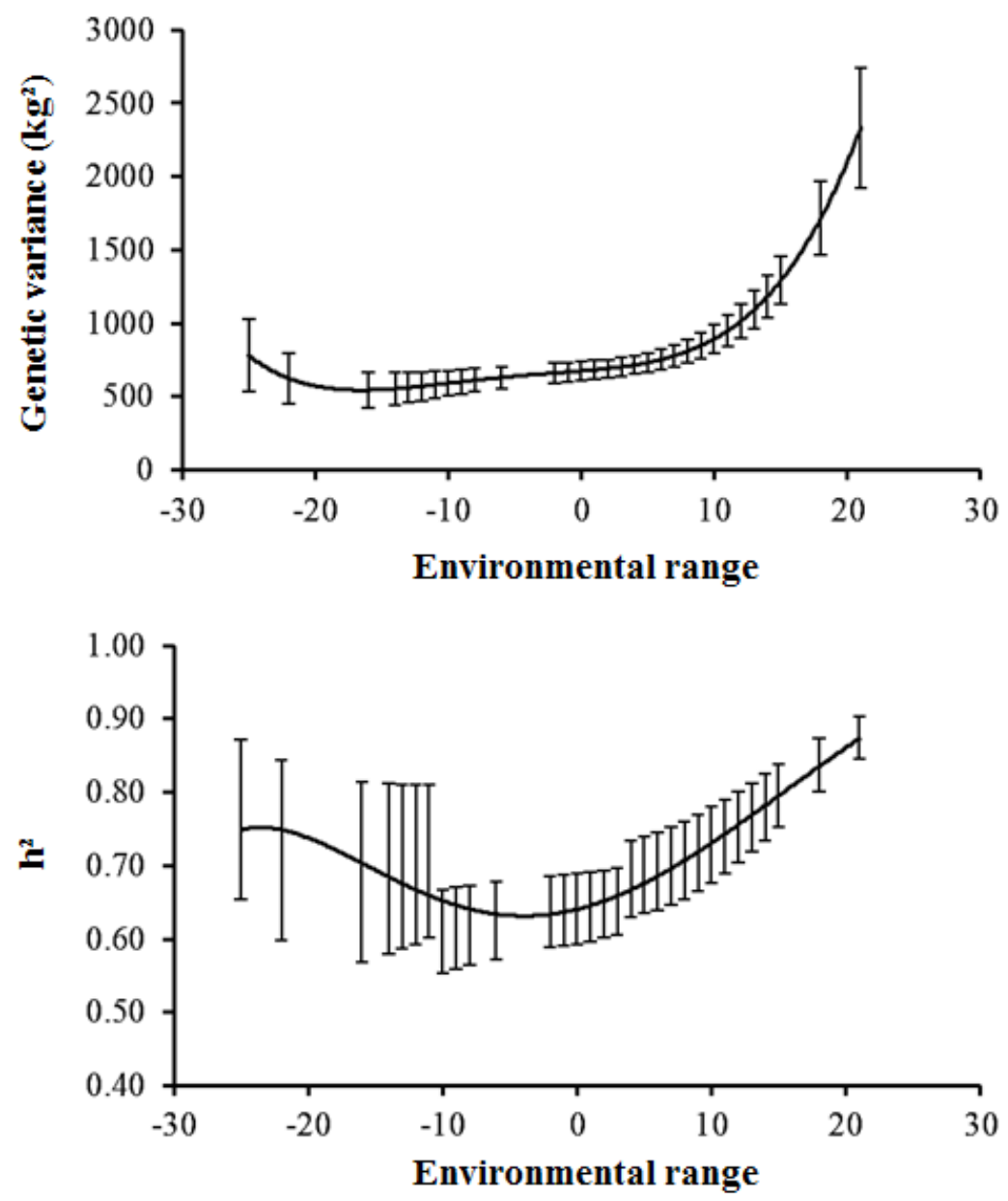

The correlation between the intercept and slope for $365 \mathrm{~W}$ were slightly high, which is indicative of the reclassification of the animals in different environments. Therefore, the best animals in a given environment are not necessarily the best in another environment. Santana Júnior et al. (2014) provided similar reasoning for the correlation between the intercept and the slope when studying calf weaning weight (0.40) in Brazil.

It was shown that heritability increases when conditions in the environment improve (Figure
2). Therefore, greater responses to selection may be expected in favorable and intermediate environments. Mattar et al. (2011), studying body weight at 420 days in Canchim cattle (5/8 Charolais, 3/8 Zebu) and Cardoso and Tempelman (2012) analyzing post-weaning weight in Brazilian Angus cattle both reported a similar trend when working with reaction norms.

Table 4 displays offspring averages of the five best bulls in each state and do not characterize the trajectory of their mean EPDs according to the 
environment range. The spatialization of the bulls' EPDs is shown according to the environmental range within each state (Figure 3). The concave shape of trends denotes environmental sensitivity of each animal in front of possible environmental changes.

Table 4. Classification (mean EPD for W365 in kg) of the five best bulls in each state, compared to those in the other states under analysis.

\begin{tabular}{|c|c|c|c|}
\hline & Pará & Tocantins & Maranhão \\
\hline \multirow{5}{*}{ 䨔 } & 1st (7.63) & 1st (16.77) & 2nd (6.48) \\
\hline & 2nd (5.53) & 2nd (8.12) & 1 st (8.42) \\
\hline & 3rd (4.69) & $3 \operatorname{rd}(6.13)$ & 5th (4.82) \\
\hline & 4th $(4.42)$ & 5 th $(5.18)$ & 7 th $(3.77)$ \\
\hline & 5 th $(4.08)$ & 28th $(0.36)$ & 29 th $(-0.08)$ \\
\hline \multirow{5}{*}{ 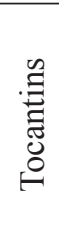 } & 1st (7.63) & 1st (16.77) & 2nd (6.48) \\
\hline & 2nd (5.53) & 2nd (8.12) & 1 st $(8.42)$ \\
\hline & $3 \mathrm{rd}(4.69)$ & $3 \mathrm{rd}(6.13)$ & 5 th $(4.82)$ \\
\hline & 7 th $(3.98)$ & 4th $(5.27)$ & 8th (3.46) \\
\hline & 4th (4.42) & 5th $(5.18)$ & 7 th $(3.77)$ \\
\hline \multirow{5}{*}{ 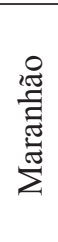 } & 2nd (5.53) & 2nd (8.12) & 1st (8.42) \\
\hline & $1 \mathrm{st}(7.63)$ & 1st (16.77) & 2nd (6.48) \\
\hline & 9th (3.84) & 7 th $(4.86)$ & 3rd (5.81) \\
\hline & 34th $(-1.21)$ & 35 th $(-0.83)$ & 4th $(5.72)$ \\
\hline & $3 \mathrm{rd}(4.69)$ & $3 \mathrm{rd}(6.13)$ & 5th $(4.82)$ \\
\hline
\end{tabular}

Slopes demonstrate the effect of the reaction norm for the same animal in different environments since the coefficient of linear regression represents the magnitude of the slope of the reaction norm. Therefore, greater slopes correspond to greater environmental sensitivity and genetic change in the classification of bulls is obtained according to changes in the environmental range. The reaction norm model with linear random regression presupposes that reaction norms are linear. In other words, the animals respond linearly to a continuous environmental range.

According to Valente (2007), two random coefficients of regression (intercept and linear) are attributed to each animal. They are used to predict the breeding value for all animals in every environment. Higher rates of linear regression coefficients mean higher sensitivity of animals to environmental change. Lira (2014) analyzed GxE by reaction norm in Nellore cattle in the Brazilian tropics and also reported a scale effect through environmental ranges, with an increase of breeding value in bulls when improvement in the environment occurred.

It should be noted that the three best bulls in Pará and Tocantins were the same,though their $365 \mathrm{~W}$ EPDs were different. However, the magnitudes of their EPDs were different between these states. The $1^{\text {st }}, 2^{\text {nd }}$ and $3^{\text {rd }}$ best bulls in the state of Pará had average progeny $365 \mathrm{~W}$ EPDs of $7.63 \mathrm{~kg}, 5.53 \mathrm{~kg}$ and $4.69 \mathrm{~kg}$, respectively, whereas their average progeny EPDs in the state of Tocantins were $16.77 \mathrm{~kg}, 8.12 \mathrm{~kg}$ and $6.13 \mathrm{~kg}$, respectively.

Maranhão had the greatest difference in the classification of its top five bulls, with no similarities with the other states (Table 4). These results demonstrate the differences of the same genotype for different environments and thus the importance 
of accounting for a genotype by environment interaction in genetic evaluation programs. This is especially true in Brazil due to its highly differentiated environments and management settings.

Figure 3. Reaction norm of expected progeny difference (EPD) of the five best bulls (1, 2, 3, 4 and 5) for 365W of Nellore cattle in Pará, Maranhão and Tocantins.

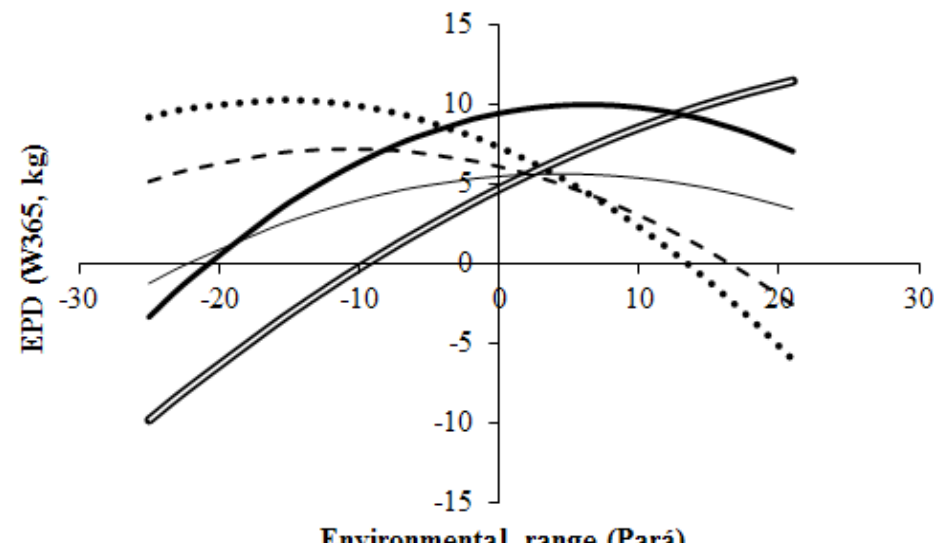

Environmental range (Pará)

—Sire $1 \quad \cdots$ Sire $2 \quad--$ Sire $3 \longrightarrow$ Sire 4 Sire 5



Environmental range (Tocantins)

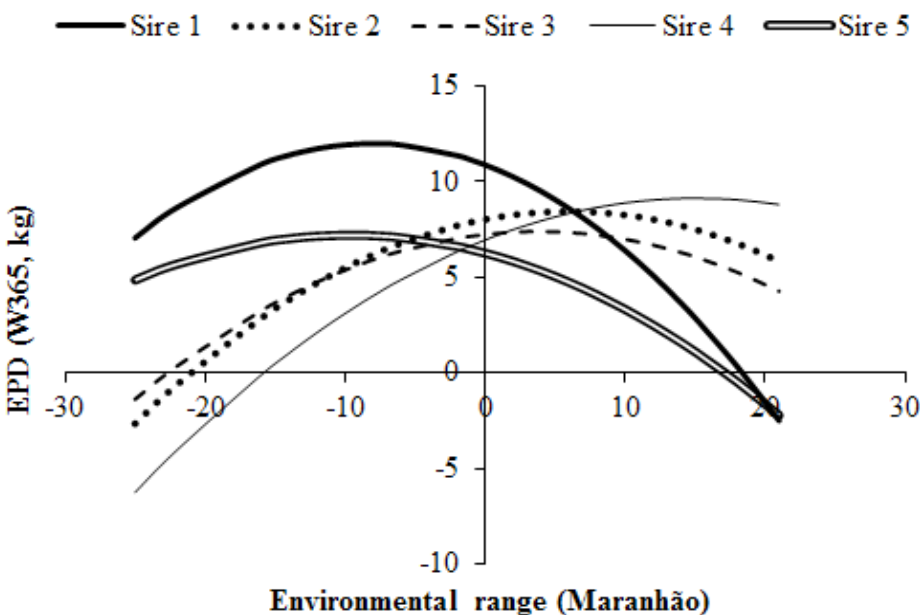

$\longrightarrow$ Sire $1 \quad \cdots$ Sire $2 \quad--$ Sire $3 \longrightarrow$ Sire $4{ }_{\text {Sire }} 5$ 


\section{Conclusion}

The reaction norm model was effective at detecting GxE due to a high variability of estimated breeding values in extreme environments. This model has the advantage of estimating breeding values for each environment because it estimates genetic parameters for each environment. The reaction norm model was able to visualize GxE in a Nellore population in that consisted of genetically related animals in the states of Maranhão, Pará and Tocantins. Selection response varies according to the environment and the genetic trends of each animal indicate that the population is reaching a greater plasticity. This should give great concern to breeders since a greater plasticity seems to limit heritability and selection responses.

\section{Acknowledgements}

The authors are grateful to the Federal University of Tocantins (Financial support process Propesq/ UFT $n^{\circ}$ 21/2014), the Brazilian Association of Zebu Breeders, the Brazilian Institute of Geography and Statistics, the National Institute of Meteorology, the National Institute for Space Research and the United States Geological Survey for the phenotypic and environmental datasets provided for this study.

\section{References}

BERTRAND, J. K.; HOUGH, J. D.; BENYSHEK, L. L. Sire $x$ environment interactions and genetic correlations of sire progeny performance across regions in dam-adjusted field data. Journal of Animal Science, Champaign, v. 64, n. 1, p. 77-82, 1987.

BLACKBURN, H.; LEBBIE, S. H. B.; VAN DE ZIJPP, A. J. Animal genetic resources and sustainable development. In: WORLD CONGRESS ON GENETICS APPLIED TO LIVESTOCK PRODUCTION, 6., 1998, Armidale. Proceedings... Armidale: UNE/FAO, 1998. v. 28, p. 3-10.

BOLIGON, A. A.; BALDI, F.; MERCADANTE, M. E. Z.; LÔBO, R. B.; ALBUQUERQUE, L. G. Multi-trait and random regression mature weight heritability and breeding value estimates in Nelore cattle. South African Journal of Animal Science, Champaign, v. 39, n. 1, p. 145-148, 2009.
BOLIGON, A. A.; MERCADANTE, M. E. Z.; BALDI, F.; LÔBO, R. B.; PEREIRA, R. J.; ALBUQUERQUE, L. G. Breeding value accuracy estimates for growth traits using random regression and multi-trait models in Nelore cattle. Genetics and Molecular Research, Ribeirão Preto, v. 10, n. 2, p. 1227-1236, 2011.

CAMPÊLO, J. E. G.; LOPES, P. S.; TORRES, R. A.; EUCLYDES, R. F.; SILVA, L. O. C.; ARAÚJO, C. V.; PEREIRA, C. S. Heterogeneidade de variâncias da avaliação genética de bovinos da raça Tabapuã em analises com efeito materno. Revista Cientifica de Produção Animal, Teresina, v. 3, n. 1, p. 83-96, 2001.

CARDOSO, F. F.; CARDELLINO, R. A.; CAMPOS, L. T. (Co)variance components and genetic parameters of post-weaning traits in Angus cattle. Revista Brasileira de Zootecnia, Viçosa, MG, v. 33, n. 2, p. 313-319, 2004.

CARDOSO, F. F.; TEMPELMAN, R. J. Linear reaction norm models for genetic merit prediction of Angus cattle under genotype by environment interaction. Journal of Animal Science, Champaign, v. 90, n. 7, p. 2130-2141, 2012.

CARDOSO, L. L.; BRACCINI NETO, J.; CARDOSO, F. F.; COBUCI, J. A.; BIASSUS, I. O.; BARCELLOS, J. O. $\mathrm{J}$. Hierchical bayesian models for genotype $\mathrm{x}$ environment estimates in post-weaning gain of Hereford bovine via reaction norms. Revista Brasileira de Zootecnia, Viçosa, MG, v. 40, n. 2, p. 294-300, 2011.

CORRÊA, M. B. B.; DIONELLO, N. J. L.; CARDOSO, F. F. Genotype by environment interaction characterization and model comparison for post weaning gain adjustment of Devon cattle via reaction norms. Revista Brasileira de Zootecnia, Viçosa, MG, v. 38, n. 8, p. 1460-1467, 2009.

DIVISÃO DE SATÉLITE E SISTEMAS AMBIENTAIS - DAS. Índice de vegetação por diferença normalizada. Instituto Nacional de Pesquisas Espaciais. 2011. Disponível em: $<$ http://satelite.cptec.inpe.br/NIVD/info_ NIVD.jsp>. Acesso em: 18 ago. 2012.

DUBEUF, J. P.; BOYAZOGLU, J. An international panorama of goat selection and breeds. Livestock Science, London, v. 120, n. 3, p. 225-231, 2009.

ENCARNAÇÃO, R. O. Estresse e produção animal. In: CICLO INTERNACIONAL DE PALESTRAS SOBRE BIOCLIMATOLOGIA ANIMAL, 1989, Botucatu. Anais... Jaboticabal: FUNEP, 1989. p. 111-129.

FIKSE, W. F.; REKAYA, R.; WEIGEL, K. A. Assessment of environmental descriptors for studying genotype by environment interaction. Livestock Production Science, London, v. 82, n. 2-3, p. 223-231, 2003. 
JONG, G. de; BIJMA, P. Selection and phenotypic plasticity in evolutionary biology and animal breeding. Livestock Production Science, London, v. 78, n. 3, p. 195-214, 2002.

KIRKPATRICK, M.; HECKMAN, N. A. Quantitative genetic model for growth, shape and other infinite dimensional characters. Journal of Mathematical Biology, Verlage, v. 27, n. 4, p. 429-450, 1990.

KOLMODIN, R.; STRANDBERG, E.; DANELL, B.; JORDANI, H. Reaction norms for protein yield and days open in Swedish Red and White dairy cattle in relation to various environmental variables. Acta Agriculturae Scandinavica, Section A - Animal Science, Norway, v. 54, n. 3, p. 139-151, 2004.

KOLMODIN, R.; STRANDBERG, E.; MADSEN, P.; JENSEN, J.; JORDANI, H. Genotype by environment interaction in Nordic dairy cattle studied using reaction norms. Acta Agriculturae Scandinavica, Section A Animal Science, Norway, v. 52, n. 1, p. 11-24, 2002.

LIRA, T. S. Interação genótipo-ambiente em bovinos da raça Nelore por meio de modelo de norma de reação. 2014. Dissertação (Mestrado em Ciência Animal Tropical) - Universidade Federal do Tocantins, Araguaína.

LOPES, F. B.; SILVA, M. C.; MIYAGI, F. S.; FIORAVANTI, F. C. S.; FACÓ, O.; GUIMARÃES, R. F. C.; JÚNIOR, O. A.; MCMANUS, C. M. Spatialization of climate, physical and socioeconomic factors that affect the dairy goat production in Brazil and their impact on animal breeding decisions. Pesquisa Veterinária Brasileira, Seropédica, v. 32, n. 11, p. 1073-1081, 2012.

LOPES, J. S.; RORATO, P. R. N.; WEBER, T.; BOLIGON, A. A.; COMIN, J. G.; DORNELLES, M. A. Efeito da interação genótipo $\mathrm{x}$ ambiente sobre o peso ao nascimento, aos 205 e aos 550 dias de idade de bovinos da raça Nelore na Região Sul do Brasil. Revista Brasileira de Zootecnia, Viçosa, MG, v. 37, n. 1, p. 5460, 2008.

MACEDO, O. J.; BARBIN, D.; MOURÃO, G. B. Genetic parameters for post weaning growth of Nellore cattle using polynomials and trigonometric functions in random regression models. Scientia Agricola, Piracicaba, v. 66, n. 4, p. 522-528, 2009.

MARTINS, J. L. Avaliação da qualidade térmica do sombreamento natural de algumas espécies arbóreas, em condições de pastagem. 2001. Dissertação (Mestrado em Engenharia Agrícola) - Universidade Estadual de Campinas, Campinas.
MATTAR, M.; SILVA, L. O. C.; ALENCAR, M. M., CARDOSO, F. F. Genotype $\times$ environment interaction for long-yearling weight in Canchim cattle quantified by reaction norm analysis. Journal of Animal Science, Champaign, v. 89, n. 8, p. 2349-2355, 2011.

MCMANUS, C.; COBUCI, J.; BRACCINI NETO, J.; PAIVA, S. Decision making in animal breeding programs and their consequences for animal production. Revista Brasileira de Reprodução Animal, Belo Horizonte, v. 35, n. 2, p. 69-76, 2011.

MEYER, K. WOMBAT - A program for mixed models analyses in quantitative genetics by REML. Journal of Zhejiang University SCIENCE B, Zhejiang, v. 8, n. 11, p. 815-821, 2007.

OLESEN, I.; GOREN, A. F.; GJERDE, B. Definition of animal breeding goals for sustainable production systems. Journal of Dairy Science, Champaign, v. 78, n. 3, p. 570-582, 2000.

PEGOLO, N. T. Interação genótipo-ambiente $e$ sensibilidade ambiental em características de crescimento em bovinos de corte. 2005. Dissertação (Mestrado em Ciência Animal) - Faculdade de Medicina Veterinária e Zootecnia, FMVZ-UNESP, Botucatu.

PONZONI, F. P.; SHIMABUKURO, Y. E. Sensoriamento remoto no estudo da vegetação. São José dos Campos: Parêntese, 2007. 144 p.

RIBEIRO, S.; ELER, J. P.; BALIEIRO, J. C. C.; FERRAZ, J. B. S.; PEDROSA, V. B.; MATTOS, E. C. Influência da interação genótipo $\mathrm{x}$ ambiente sobre $\mathrm{o}$ peso à desmama em bovinos da raça Nelore. Arquivo Brasileiro de Medicina Veterinária e Zootecnia, Belo Horizonte, MG, v. 61, n. 3, p. 668-675, 2009.

ROSO, V. M.; SCHENKEL, F. S. AMC - a computer program to assess the degree of connectedness among contemporary groups. In: WORLD CONGRESS ON GENETICS APPLIED TO LIVESTOCK PRODUCTION, 8., 2006, Belo Horizonte. Proceedings... Belo Horizonte: [s.n.], 2006. p. 27-26.

SANTANA JÚNIOR, M. L.; ELER, J. P.; CARDOSO, F. F.; ALBUQUERQUE, L. G.; FERRAZ, J. B. S. Phenotypic plasticity of composite beef cattle performance using reaction norms model with unknown covariate. Animal, Cambridge, UK, v. 7, n. 2, p. 202-210, 2014.

STATISTICAL ANALYSIS SYSTEM INSTITUTE SAS. Institute Inc. Statistical Analysis System user's guide. Version 9.0 ed. Cary: SAS Institute, USA, 2002. 
SILVA, B. B.; LOPES, G. M.; AZEVEDO, P. V. Determinação do albedo de áreas irrigadas com base em imagens Landsat 5 MT. Revista Brasileira de Agrometeorologia, Sete Lagoas, MG, v. 13, n. 2, p. 201211, 2007.

SILVA, R. G. Introdução à bioclimatologia animal. São Paulo: Nobel, 2000. 286 p.

SU, G.; MADSEN, P.; LUND, M. S. Bayesian analysis of the linear reaction model with unknown covariates. Journal of Animal Science, Champaign, v. 84, n. 7, p. 1651-1657, 2006.
VALENTE, B. D. Estruturas de covariancias de peso em função da idade dos animais Nelore das regiões sudeste e centro-oeste. 2007. Dissertação (Mestrado em Ciência Animal) - Universidade Federal de Minas Gerais, Belo Horizonte.

VIA, S.; LANDE, R. Genotype-environment interaction and the evolution of phenotypic plasticity. Evolution, Lawrence, v. 39, n. 3, p. 505-522, 1984. 
